Zeszyty Naukowe Szkoły Głównej Gospodarstwa Wiejskiego w Warszawie

Problemy Rolnictwa Światowego tom 18 (XXXIII), zeszyt 3, 2018: 49-58

DOI: 10.22630/PRS.2018.18.3.65

Katarzyna Brodzińska ${ }^{1}$

Uniwersytet Warmińsko-Mazurski w Olsztynie

\title{
Ekologizacja rolnictwa w aspekcie polityki finansowego wsparcia
}

\section{The Ecologization of Agriculture in Aspect of Financial Support Policy}

\begin{abstract}
Synopsis. Celem artykułu jest rozpoznanie procesu ekologizacji rolnictwa w Polsce przy uwzględnieniu światowych tendencji rozwoju rolnictwa ekologicznego i realizowanej polityki wsparcia finansowego w ramach WPR. W analizach wykorzystano dane statystyczne Międzynarodowej Federacji Rolnictwa Ekologicznego - IFOAM i Instytutu Badań Rolnictwa Ekologicznego - FIBL oraz Głównego Inspektoratu Jakości Handlowej Artykułów Rolno-Spożywczych - GIJHARS. Z przeprowadzonych analiz wynika, że proces ekologizacji rolnictwa przebiega w różnym tempie na poszczególnych kontynentach, ale to właśnie w Europie wzrasta zarówno powierzchnia upraw, jak i dynamicznie rozwija się rynek ekologicznych produktów żywnościowych. W Polsce duży wpływ na proces ekologizacji rolnictwa ma realizowana polityka wsparcia finansowego, a powodzenie tego procesu zależy od umocnienia rynkowego ekologicznych gospodarstw rolnych (wzrostu towarowości i skrócenia łańcucha dostaw żywności) oraz budowania świadomości ekologicznej konsumentów.
\end{abstract}

Słowa kluczowe: rolnictwo ekologiczne, wspólna polityka rolna (WPR), wsparcie finansowe

\begin{abstract}
The aim of the article is to recognize the process of greening of the agriculture in Poland in terms of worldwide development tendencies and the policy of financial support under the CAP. Analyses were conducted using statistical data from the International Federation of Organic Agriculture - IFOAM, the Institute of Organic Farming Research - FIBL and the Main Inspectorate of Trade Quality of Agricultural and Food Products - GIJHARS. Analyses showed that the process of greening of the agriculture is proceeding at different speeds on individual continents, but it is in Europe that both the area of cultivation and the market for organic food products is rapidly growing. In Poland, the implemented policy of financial support has a major impact on the process of greening of the agriculture, and the success of this process depends on the market strengthening of ecological farms (increase in commodity and shortening the food supply chain) and building ecological awareness of consumers.
\end{abstract}

Key words: organic farming, common agricultural policy (CAP), financial support

JEL Classification: Q18

\section{Wprowadzenie}

Pojęcie ekologizacji jest starą kategorią związaną z gospodarką leśną, łowiecka, rybacką, pszczelarską, jak również rolnictwem. Termin ten określa wykorzystanie naturalnych mechanizmów dla wzmocnienia procesów gospodarczych (Famielec 2015). Ekologizacja nawiązuje do uniwersalnych praw obowiązujących w przyrodzie, gdzie każdy

${ }^{1}$ dr hab. inż., Katedra Agrotechnologii, Zarządzania Produkcją Rolniczą i Agrobiznesu UWM w Olsztynie, ul. M. Oczapowskiego 8,10-719 Olsztyn, e-mail: katarzyna.brodzinska@uwm.edu.pl; https://orcid.org/0000-0003-1329-2391 
skutek ma swoją przyczynę, gdzie istnieje spójność wszystkiego ze wszystkim, rzeczy są ważne i mniej ważne, a świadomość decyduje o harmonijnym rozwoju (Kozłowski 1997). W tym kontekście rolnictwo ekologiczne jako system oparty na wykorzystaniu naturalnych procesów zachodzących w obrębie gospodarstwa rolnego idealnie wpisuje się w nurt ekologizacji. Trzeba jednak pamiętać, że celem rolnictwa ekologicznego jest nie tylko ochrona środowiska przyrodniczego ale również, a może nawet przede wszystkim, produkcja żywności. O ile rolnictwo ekologiczne wpisuje się w nurt ekologizacji, o tyle transport ekologicznych produktów żywnościowych na znaczne odległości, z pewnością już nie. Chodzi bowiem o to, by przeciwdziałać zmianom klimatu, a w tej kwestii redukcja $\mathrm{CO} 2$ (również z transportu) jest kluczowa.

W szerokim kontekście interpretacji tego terminu, ,ekologizacja” to dążenie do zmian strukturalnych w całej gospodarce oraz przekształceń poszczególnych jej gałęzi w celu zmniejszenia zużycia energii, surowców i wody, zmniejszenia ilości wytwarzanych zanieczyszczeń i ich uciążliwości dla środowiska oraz społeczności. Wpływa ona na wszystkie sektory oraz na makro- i mikroekonomiczne zjawiska. Poprawnie rozumiana ekologizacja to nie tylko uwzględnianie ograniczeń ekologicznych - konieczności ochrony przyrody, ale także uwzględnianie wszelkich aspektów społecznych, związanych z człowiekiem (Famielec 2015). Reasumując, ekologizacja jest kategorią znacznie pojemniejszą i jest najczęściej utożsamiana z przyrodniczymi uwarunkowaniami procesów gospodarczych, co oznacza partnerskie współdziałanie dla dobra wszystkich ludzi oraz środowiska przyrodniczego, wspomagane nauką i wysoką techniką oraz kulturą informacyjną (Michnowski 2014).

Proces ekologizacji rolnictwa w Polsce można rozpatrywać w oparciu o dorobek ekonomii instytucjonalnej oraz teorii wyboru publicznego (Uwarunkowania... 2017). Jest to zasadne ponieważ, od czasu wprowadzenia w 2004 roku instrumentarium interwencji w ramach WPR, proces ekologizacji rolnictwa nabrał wyraźnego przyspieszenia. Podstawą ukierunkowania polityki rolnej i implementacji pomocy finansowej na rozwój rolnictwa ekologicznego jest zmiana priorytetów WPR w kierunku przeciwdziałania negatywnym skutkom zmian klimatu, konieczności podejmowania działań na rzecz ochrony środowiska, czy zapewnienia bezpieczeństwa żywnościowego i bezpieczeństwa żywności. W opinii Goraja (2013) rosnący brak akceptacji społecznej dla dalszej intensyfikacji produkcji rolnej kosztem bezpieczeństwa, walorów zdrowotnych i smakowych oraz dalszego zanieczyszczania środowiska naturalnego stwarza szansę na rozwój rolnictwa ekologicznego tym bardziej, że jego istota wpisuje się w nowe koncepcje rozwoju, jak np. zrównoważona intensyfikacja (sustainable intensification), gospodarka cyrkulacyjna (circular economy), czy zielona gospodarka (bio economy). Należy jednak w tym miejscu zadać pytanie o efektywność zainwestowanych w ramach WPR środków finansowych w rozwój rolnictwa ekologicznego. Czy i w jakim stopniu środki te przyczyniły się do umocnienia gospodarstw ekologicznych, a na ile stały się narzędziem w pogoni za rentą, definiowaną jako niezasłużona korzyść lub nagroda niepowiązana z pomnażaniem zasobów lub ponoszonym wysiłkiem na konkurencyjnym rynku (Zawojska 2011). W opinii Zybertowicza (2010) im bardziej w danym kraju jest rozbudowana polityczna pogoń za renta, tym mniej efektywna jest modernizacja i tym trudniej jest realizować zasady spójności społecznej. Jest to wynik tego, że ta część zasobów, która zostaje angażowana w polityczną pogoń za renta, nie zostaje zainwestowana produkcyjnie, a zatem pogarsza się efektywność alokacji zasobów gospodarczych. Wiele wskazuje, że w przypadku rolnictwa ekologicznego taka sytuacja może mieć miejsce. W związku z powyższym celem artykułu 
jest rozpoznanie procesu ekologizacji rolnictwa $\mathrm{w}$ Polsce $\mathrm{w}$ aspekcie realizowanej polityki wsparcia finansowego.

\section{Dane i metody}

Materiał źródłowy stanowiły dane statystyczne Międzynarodowej Federacji Rolnictwa Ekologicznego - IFOAM i Instytutu Badań Rolnictwa Ekologicznego - FIBL oraz Głównego Inspektoratu Jakości Handlowej Artykułów Rolno-Spożywczych - GIJHARS. W toku badań wykorzystano metody statystyki opisowej oraz metody prezentacji tabelarycznej i graficznej.

W kontekście międzynarodowym analizowano tendencje rozwoju rolnictwa ekologicznego i możliwości jego rozwoju z uwzględnieniem siły nabywczej rynków krajowych. Na poziomie krajowym analizy prowadzono pod kątem oceny wyników produkcyjnych gospodarstw ekologicznych i ich relacji w stosunku do wyników produkcyjnych osiaganych w gospodarstwach konwencjonalnych. Takie ujęcie analiz nie wyczerpuje oczywiście problemu badawczego, ale stanowi ważne ujęcie w analizie procesu ekologizacji polskiego rolnictwa.

\section{Tendencje w rozwoju rolnictwa ekologicznego na świecie a rynek żywności ekologicznej}

Rosnące zainteresowanie rozwojem rolnictwa ekologicznego w skali całego świata dowodzi, że jest to perspektywiczny system produkcji. Rośnie zainteresowanie rolników prowadzeniem produkcji w systemie ekologicznym oraz dynamicznie rozwija się rynek produktów ekologicznych w Europie i na świecie. W skali świata w 2016 roku zdecydowanie największa powierzchnia pod uprawami ekologicznymi znajdowała się na kontynencie australijskim i przyległych wyspach Oceanu Spokojnego (Oceania - 27,3 mln ha, czyli ok. $45 \%$ światowej powierzchni upraw ekologicznych). Duży potencjał ma również Europa $(13,5 \mathrm{mln}$ ha, czyli ok. $25 \%$ światowej powierzchni), w tym Unia Europejska $(11,1 \mathrm{mln}$ ha, czyli ponad $20 \%)$. Warto podkreślić, że na wyspach Oceanu Spokojnego i w Australii, wzrost powierzchni miał charakter skokowy. W latach 20082012 powierzchnia upraw ekologicznych obejmowała ok. $12 \mathrm{mln}$ ha, w 2014 roku wzrosła do $18,5 \mathrm{mln}$ ha, a w roku 2016 aż do $27,3 \mathrm{mln}$ ha. W tym rejonie świata występuja specyficzne warunki klimatyczne. Znaczną część gruntów ekologicznych (ponad 90\%) w Australii stanowią pastwiska. Ta specyfika sprawia, że region ten cechuje się najwyższą średnią powierzchnią ekologicznych użytków rolnych przypadających na producenta ekologicznego (ponad 750 ha) (Luty 2016).

W Europie natomiast odnotowuje się stałą tendencję wzrostową powierzchni ekologicznych gospodarstw rolnych. Jest to wzrost rzędu 5-20\% w okresach dwuletnich (2008 - 8,3 mln ha, 2010 - 10,0 mln ha, 2012 - 11,2 mln ha, 2014 - 11,8 mln ha, $2016-$ $13,5 \mathrm{mln}$ ha). Na pozostałych kontynentach, $\mathrm{z}$ wyjątkiem Afryki, gdzie powierzchnia wzrosła dwukrotnie (z 0,9 mln ha w 2008 roku do $1,8 \mathrm{mln}$ ha w 2016 roku), nie odnotowano w tym okresie wyraźnych tendencji wzrostowych (The world... 2018).

Wzrostowi powierzchni upraw ekologicznych towarzyszył również szybki rozwój rynku produktów ekologicznych na świecie. Globalny rynek rolniczych produktów ekologicznych zwiększył się w latach 2001-2016 z 21 mld USD do 89,7 mld USD) czyli ponad czterokrotnie. W tym samym czasie wrosła również globalna powierzchnia upraw 
ekologicznych z 17,3 mln ha do 57,8 mln ha, czyli ponad trzykrotnie. Ponieważ tempo wzrostu wartości sprzedaży żywności ekologicznej jest szybsze niż powierzchni upraw ekologicznych, rokuje to dobrze na perspektywy rozwoju rolnictwa ekologicznego. Dotyczy to szczególnie Europy, gdyż w 2016 roku w pierwszej dziesiątce krajów z największą konsumpcją produktów ekologicznych przypadającą na jednego mieszkańca w skali świata znalazło się aż osiem krajów z Europy (Szwajcaria - 274 euro, Dania - 227 euro, Szwecja 197 euro, Luksemburg - 188 euro, Lichtenstein - 171 euro, Austria 177 euro, Niemcy 116 euro, Francja - 101 euro), a w Austrii wydatki te w stosunku do 2017 roku wzrosły aż o blisko $40 \%$. Poza krajami europejskimi, wśród krajów o największej konsumpcji znalazły się również USA (121 euro/osoba) i Kanada (83 euro/osoba). Jest to o tyle istotne, że w kontekście wspomnianych nowych koncepcji rozwoju krajowe (lokalne, regionalne) rynki żywności ekologicznej mogą okazać się kluczowe.

Jak wynika z danych FiBL w latach 2006-2016 spadek powierzchni ekologicznych upraw odnotowano w 21 krajach świata, przy czym nie wystapił on w żadnym kraju europejskim. Natomiast w latach 2015-2016 liczba państw, w których ten spadek miał miejsce wzrosła do 40 i wystąpiła w trzech krajach europejskich: Grecji, Rumunii i Polsce (tab.1).

Tabela. 1. Wybrane parametry charakteryzujące rolnictwo ekologiczne i obrót produktami ekologicznymi w wybranych krajach świata

Table 1. Selected parameters characterizing organic farming and trade in organic products in selected countries of the world

\begin{tabular}{|c|c|c|c|c|}
\hline Kraj & $\begin{array}{l}\text { Powierzchnia } \\
\text { ekologicznych użytków } \\
\text { rolnych w 2016roku } \\
\text { (ha) }\end{array}$ & $\begin{array}{c}\text { Zmiana } \\
\text { w latach } \\
\text { 2015-2016 } \\
(\%)\end{array}$ & $\begin{array}{c}\text { Zmiana } \\
\text { w latach } \\
\text { 2006-2016 } \\
(\%)\end{array}$ & $\begin{array}{c}\text { Sprzedaż produktów } \\
\text { ekologicznych } \\
\text { w } 2016 \text { roku } \\
\text { (EUR/osoba) }\end{array}$ \\
\hline Australia & 27145021 & $+22,8$ & $+126,4$ & $40 *$ \\
\hline USA & 2031318 & $+0,1$ & $+17,0$ & 121 \\
\hline Kanada & 1099014 & 16,4 & 97,4 & 83 \\
\hline Austria & 571585 & $+3,3$ & $+9,9$ & 177 \\
\hline Grecja & 342584 & $-15,8$ & $+22,4$ & 5 \\
\hline Niemcy & 1251320 & $+14,9$ & $+44,6$ & 116 \\
\hline Francja & 1538047 & $+16,3$ & $+176,0$ & 101 \\
\hline Dania & 201476 & $+20,8$ & $+36,7$ & 227 \\
\hline Polska & 536579 & $-7,6$ & $+87,7$ & 4 \\
\hline Rumunia & 226309 & $-8,0$ & $+72,2$ & 4 \\
\hline Włochy & 1796363 & $+20,4$ & $+56,2$ & 44 \\
\hline Szwecja & 552695 & $+6,5$ & $+79,3$ & 197 \\
\hline Szwajcaria & 141249 & $+2,9$ & $+21,9$ & 274 \\
\hline Świat & 57816759 & $+15,0$ & $+83,5$ & - \\
\hline
\end{tabular}

Źródło: opracowanie własne na podstawie danych FiBl\&IFOAM The World of Organic Agriculture 2018. * - 2015.

Sytuacja gospodarcza europejskich krajów, w których odnotowano spadek powierzchni upraw ekologicznych wydaje się być zróżnicowana. Z jednej strony Grecja $\mathrm{i}$ wielki kryzys gospodarczy w tym kraju, z drugiej Rumunia - kraj dynamicznie się 
rozwijający w ostatnim okresie, głównie za sprawą niższych podatków i wyższych płac oraz Polska - z wysoką dynamiką wzrostu gospodarczego i programem 500+. To, co łączy te trzy kraje, to niski poziom wydatków na żywność ekologiczną, rzędu 4-5 euro/osobę.

Rynek żywności ekologicznej posiada swoją specyfikę, która jest uwarunkowana swoistymi zachowaniami i świadomością ekologiczną konsumentów, stopniem rozwoju gospodarczego i poziomem dochodów ludności, prowadzoną polityką rolną oraz warunkami naturalnymi panującymi na terenie poszczególnych krajów (Domagalska, Buczkowska, 2015). Warto podkreślić, że rozwój rynku żywności ekologicznej wynika nie tylko z wysokich dochodów, ale i świadomości ekologicznej potencjalnych konsumentów. Popyt na żywność ekologiczną pojawia się dopiero wtedy jako zjawisko ekonomiczne i społeczne, kiedy tak świadomość ekologiczna, jak i wysokie dochody występują jednocześnie $\mathrm{w}$ danej kategorii konsumentów tj. gdy konsumenci o wysokim poziomie dochodów reprezentują rzeczywistą świadomość ekologiczną (Łuczka-Bakuła 1994). Z drugiej strony wysokie ceny ekologicznych produktów żywnościowych są z pewnością barierą dla ludzi o wysokiej świadomości ekologicznej ale niskich dochodach. W przypadku, gdy jedne grupy konsumentów będą reprezentowały świadomość ekologiczną, a inne wysoki poziom dochodów osobistych i brak świadomości, to na rynku nie będzie popytu na produkty ekologiczne. Oczywiście na podstawie przeprowadzonych analiz nie można wyciągać daleko idących wniosków, ale wiele wskazuje, na ograniczone możliwości rozwoju lokalnych rynków żywności ekologicznej w tych krajach, ze względu na niską siłę nabywczą ludności. Przyczyn takiego stanu rzeczy może być wiele, wspomniany niski poziom świadomości konsumentów, niski poziom dochodów, ale również brak tradycji, czy wysoka jakość smakowa żywności wyprodukowanej w systemie konwencjonalnym. Z drugiej strony spadek powierzchni upraw ekologicznych, może wynikać ze zmian w sposobie finansowania tego systemu produkcji, co najprawdopodobniej ma miejsce $\mathrm{w}$ Polsce.

\section{Rolnictwo ekologiczne w Polsce w aspekcie wsparcia finansowego WPR}

Wsparcie finansowe rolnictwa ekologicznego w ramach stosowania dotacji w II filarze WPR (program rolnośrodowiskowy) dało silny impuls wzrostu zarówno liczby ekologicznych gospodarstw rolnych, jak i ich powierzchni. Z danych GIJHARS wynika, że w latach 2003-2013 ich liczba wzrosła 11-krotnie, a powierzchnia 12-krotnie. Jednak od 2013 roku odnotowuje się zarówno spadek liczby gospodarstw ekologicznych, jak i powierzchni ekologicznych użytków rolnych (rys. 1 i 2).

W latach 2013-2016 nastapił spadek powierzchni ekologicznych użytków rolnych o $19,9 \%$ i ich liczby o $15,7 \%$. Warto również podkreślić, że największy spadek powierzchni ekologicznych użytków rolnych miał miejsce w województwie małopolskim oraz pasie województw zachodnich (zachodniopomorskie, lubuskie, dolnośląskie, opolskie, wielkopolskie), czyli w regionie o korzystnych warunkach do prowadzenia produkcji rolnej. Analiza danych GIJHARS w zakresie struktury ekologicznych użytków rolnych wskazuje, że decyzje produkcyjne beneficjentów mogą być uzależnione od zmieniających się warunków finansowania poszczególnych grup upraw, chodzi tu głównie o spadek powierzchni upraw sadowniczych oraz łąk i pastwisk w latach 2009-2016 i wzrost powierzchni upraw warzywnych od 2013 roku (rys.3). 


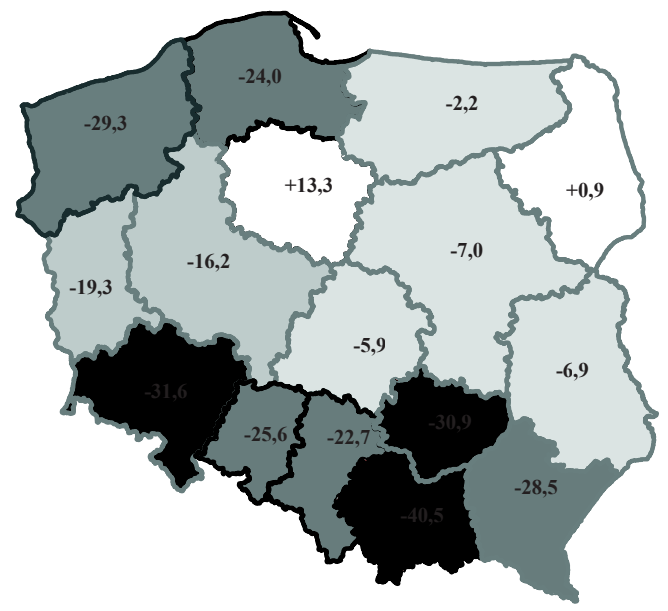

Rys. 1. Liczba gospodarstw ekologicznych. Zmiany w latach 2013-2016 [\%] [Polska -15,7\%]

Fig. 1 Number of ecological farms. Changes in 2013 2016 [\%] [Poland -15.7\%]

Źródło: opracowanie własne na podstawie GIJHARS

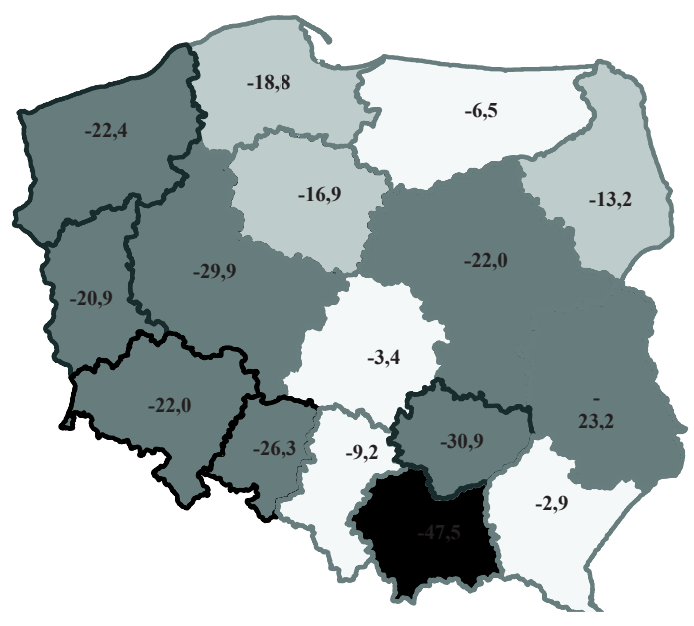

Rys. 2. Powierzchnia ekologicznych UR. Zmiany w latach 2013-2016 [\%] [Polska -19,9\%] Fig. 2. The surface of ecological UR. Changes in 2013-2016 [\%] [Poland -19.9\%]

Źródło: opracowanie własne na podstawie GIJHARS

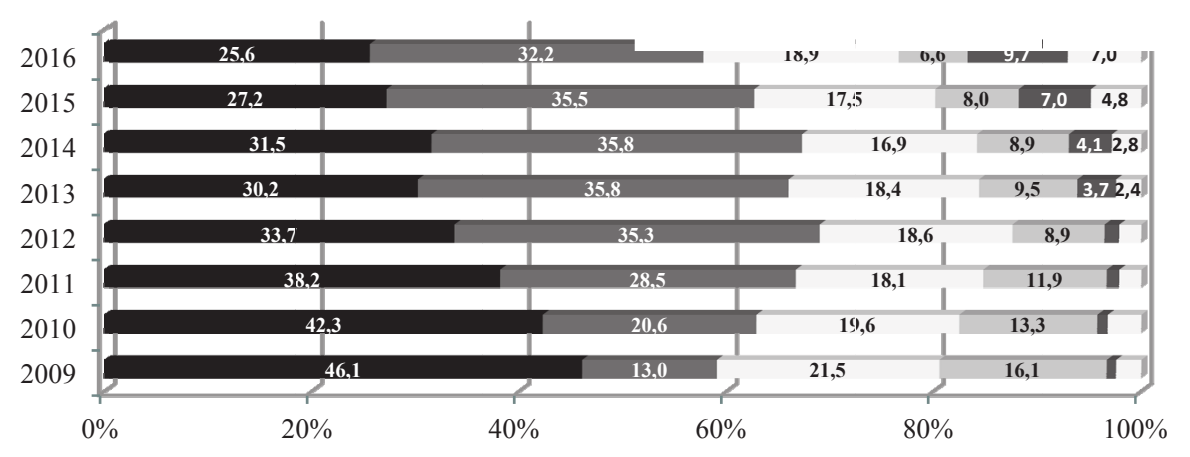

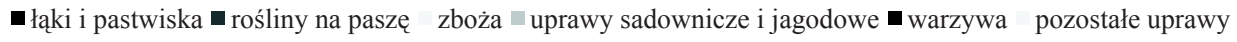

Rys. 3. Struktura upraw w rolnictwie ekologicznym w latach 2009-2016

Fig. 3. Crop structure in organic farming in 2009-2016

Źródło: opracowanie własne na podstawie danych GIJHARS

Sadek powierzchni upraw sadowniczych i jagodowych jest efektem wprowadzenia w ramach pakietu rolnictwo ekologiczne wariantu ,pozostałe uprawy sadownicze i jagodowe” o znacznie obniżonym wsparciu m.in. do sadów orzecha włoskiego. To spowodowało, że rolnicy rezygnowali z uprawy i przestawiali się na uprawę roślin na paszę, stosunkowo łatwy i dobrze płatny wariant pakietu rolnictwo ekologiczne, bez konieczności posiadania 
zwierząt gospodarskich. Wiele wskazuje, że wzrost udziału powierzchni upraw paszowych w latach 2009-2016 nastapił również kosztem powierzchni łąk i pastwisk. Ponieważ w okresie programowania 2014-2020 wsparcie to powiązano $\mathrm{z}$ obowiązkiem posiadania odpowiedniej obsady zwierząt, udział powierzchni upraw paszowych (łąki, pastwiska, rośliny na paszę) w strukturze upraw ekologicznych zaczął się zmniejszać. Zdaniem Nachtman (2013) obostrzenia co do obowiązku utrzymywania zwierząt w gospodarstwach ekologicznych, korzystających ze wsparcia w ramach PROW 2014-2020, powinny spowodować wzrost pogłowia zwierząt, ale moga i jak wynika z danych GIJHARS najprawdopodobniej skutkują rezygnacją z systemu ekologicznego.

Jednocześnie dane GIJHARS wskazuja, że od 2013 roku systematycznie wzrastała powierzchnia warzyw w uprawie ekologicznej. W latach 2012-2016 wzrosła ona więcej niż pięciokrotnie (z 9,2 tys. ha w 2012 roku do 52,0 tys. ha w 2016 roku), wiele wskazuje jednak, że jest to przede wszystkim efekt wzrostu powierzchni uprawy soczewicy jadalnej, do której od 2015 roku przysługuje również dodatkowa płatność do roślin wysokobiałkowych

\section{Produkcja towarowa gospodarstw ekologicznych}

Podstawowym miernikiem użyteczności gospodarstwa ekologicznego są nie tylko niewątpliwe korzyści środowiskowe będące efektem tego systemu gospodarowania, ale również jego produkcja towarowa. Kategorię tę definiuje się jako wartość produktów rolnospożywczych sprzedawanych przez gospodarstwo w ciagu roku (Nowogrodzka i in. 2013). Z kolei towarowość produkcji określana jako relacja wartości produkcji towarowej do produkcji globalnej, czyli wartości sprzedaży w całkowitej produkcji wytworzonej przez gospodarstwo świadczy o silniejszych związkach gospodarstwa z rynkiem.

Problemem jest pozyskanie danych dotyczących produkcji towarowej ogółu gospodarstw ekologicznych. Chodzi tu zarówno o wielkość produkcji, jak i wielkość sprzedaży ekologicznych płodów rolnych. Niemniej jednak już sama analiza wielkości produkcji, w odniesieniu do powierzchni poszczególnych grup upraw ekologicznych dowodzi niskiej, potencjalnej towarowości gospodarstw ekologicznych.

Z danych GIJHARS wynika, że udział zbóż w strukturze zasiewów kształtował się w latach 2009-2016 na poziome 16,9-21,5\%, przy czym w 2016 roku produkcja zbóż wyniosła 173 tys. ton, co w relacjach do powierzchni upraw daje plony w wysokości 1,71 t/ha (przy średnich plonach zbóż w Polsce na poziomie 4,0 t/ha). Plony zbóż ekologicznych kształtowały się na poziomie od 1,24 t/ha (woj. opolskie) do 2,46 t/ha (woj. świętokrzyskie), co stanowiło odpowiednio 20,7\% i 81,2\% plonów ogółem. W zasadzie trudno stwierdzić, z czego wynika tak duże zróżnicowanie wysokości uzyskiwanych plonów w systemie rolnictwa ekologicznego w stosunku do rolnictwa konwencjonalnego. Widać jednak wyraźne dysproporcje w relacjach województwa wschodnie (świętokrzyskie, podlaskie, podkarpackie), a województwa zachodnie (opolskie, lubuskie, zachodniopomorskie). We wspomnianym województwie opolskim plony zbóż ogółem $(5,99 \mathrm{t} / \mathrm{ha})$ są prawie dwa razy wyższe niż w woj. świętokrzyskim $(3,03 \mathrm{t} / \mathrm{ha})$, natomiast plony zbóż w rolnictwie ekologicznym mają relację odwrotną, czyli w woj. świętokrzyskim są prawie dwa razy wyższe $(2,46 \mathrm{t} / \mathrm{ha})$ niż $\mathrm{w}$ woj. opolskim $(1,24 \mathrm{t} / \mathrm{ha})$. Można przypuszczać, że w województwach gdzie relacje te są niekorzystne, czyli plony uzyskiwane w rolnictwie ekologicznym w relacji do plonów ogółem kształtują się na 
niskim poziomie, funkcjonuje wiele gospodarstw, które przeszły na ekologię by czerpać korzyści ekonomiczne głównie z subwencji rolniczych. Wykazują one powierzchnię upraw ekologicznych, ale towarowość tych upraw kształtuje się na bardzo niskim poziomie. Zestawienie danych w tabeli 1 wskazuje na pewne tendencje rozwoju gospodarstw ekologicznych w poszczególnych regionach. Nie tylko w odniesieniu do plonów zbóż, ale również owoców i warzyw, czyli upraw, które mają stosunkowo duży udział w strukturze upraw ekologicznych relacje plonów ekologicznych do konwencjonalnych nie są korzystne. W przypadku owoców najmniej korzystne relacje odnotowano w woj. lubuskim (zaledwie $1,9 \%)$, pomorskim $(4,7 \%)$ opolskim $(6,5 \%)$. W przypadku warzyw były to praktycznie wszystkie województwa z wyjątkiem podkarpackiego $(35,7 \%)$ i kujawsko-pomorskiego $(25,7 \%)$ i świętokrzyskiego (13,8\%) (tab. 3).

Tabela 2. Plony ogółem i plony w systemie rolnictwa ekologicznego w 2016 roku oraz ich wzajemne relacje

Table 2. Total yields and yields in the organic farming system in 2016 and their mutual relations

\begin{tabular}{|c|c|c|c|c|c|c|c|c|c|}
\hline \multirow[b]{2}{*}{ Wyszczególnienie } & \multicolumn{3}{|c|}{ Zboża } & \multicolumn{3}{|c|}{ Owoce } & \multicolumn{3}{|c|}{ Warzywa } \\
\hline & Ogólem & Eko & $\%$ & Ogółem & Eko & $\%$ & Ogólem & Eko & $\%$ \\
\hline dolnośląskie & 5,18 & 2,23 & 43,1 & 7,83 & 1,01 & 12,9 & 20,39 & 1,06 & 5,2 \\
\hline kujawsko-pomorskie & 4,31 & 1,61 & 37,4 & 12,12 & 2,67 & 22,0 & 22,22 & 5,72 & 25,7 \\
\hline lubelskie & 4,13 & 1,78 & 43,1 & 19,77 & 2,80 & 14,2 & 31,87 & 2,43 & 7,6 \\
\hline lubuskie & 4,22 & 1,01 & 23,9 & 13,46 & 0,25 & 1,9 & 21,54 & 0,45 & 2,1 \\
\hline łódzkie & 3,39 & 1,86 & 54,9 & 17,64 & 4,16 & 23,6 & 31,13 & 1,06 & 3,4 \\
\hline małopolskie & 4,00 & 2,44 & 61,0 & 14,26 & 3,14 & 22,0 & 30,85 & 2,97 & 9,6 \\
\hline mazowieckie & 3,11 & 1,47 & 47,3 & 20,48 & 2,33 & 11,4 & 28,73 & 0,91 & 3,2 \\
\hline opolskie & 5,99 & 1,24 & 20,7 & 10,83 & 0,70 & 6,5 & 27,89 & 0,62 & 2,2 \\
\hline podkarpackie & 3,75 & 2,44 & 65,1 & 7,57 & 4,25 & 56,1 & 19,26 & 6,87 & 35,7 \\
\hline podlaskie & 2,94 & 1,92 & 65,3 & 7,60 & 1,64 & 21,6 & 19,22 & 0,67 & 3,5 \\
\hline pomorskie & 3,94 & 1,37 & 34,8 & 8,11 & 0,38 & 4,7 & 18,69 & 0,56 & 3,0 \\
\hline śląskie & 4,44 & 1,56 & 35,1 & 6,23 & 0,81 & 13,0 & 29,12 & 0,45 & 1,5 \\
\hline świętokrzyskie & 3,03 & 2,46 & 81,2 & 16,05 & 2,97 & 18,5 & 25,13 & 3,48 & 13,8 \\
\hline warmińsko-mazurskie & 3,73 & 1,86 & 49,9 & 4,23 & 0,49 & 11,6 & 27,56 & 0,58 & 2,1 \\
\hline wielkopolskie & 4,40 & 1,84 & 41,8 & 10,81 & 2,13 & 19,7 & 26,08 & 1,54 & 5,9 \\
\hline zachodniopomorskie & 4,30 & 1,56 & 36,3 & 3,75 & 0,48 & 12,8 & 31,72 & 0,77 & 2,4 \\
\hline Polska & 4,03 & 1,71 & 42,4 & 16,61 & 1,95 & 11,7 & 25,48 & 1,05 & 4,1 \\
\hline Wspól. zmienności & 19,4 & 24,32 & 34,69 & 46,61 & 71,68 & 72,23 & 18,79 & 104,3 & 121,45 \\
\hline
\end{tabular}

Źródło: opracowanie własne na podstawie danych GIHARS

W układzie przestrzennym najkorzystniejsze wskaźniki, czyli relacje plonów osiąganych $\mathrm{w}$ systemie rolnictwa ekologicznego do plonów ogółem osiagali rolnicy z województwa podkarpackiego: zboża $-65,1 \%$, owoce $56,1 \%$, warzywa $35,7 \%$, natomiast najmniej korzystne rolnicy z województwa lubuskiego i opolskiego, odpowiednio zboża $23,9 \%$ i $20,7 \%$, owoce $1,9 \%$ i $6,5 \%$, warzywa $2,1 \%$ i $2,2 \%$ (tab. 3 ). Można w tym miejscu 
postawić pytanie, czy proces ekologizacji rolnictwa w Polsce przebiega właściwie? W jakim kierunku należy podejmować działania, aby skutecznie umocnić rynkowo gospodarstwa ekologiczne?

\section{Inicjatywy na rzecz wzmocnienia gospodarstw ekologicznych}

Wyniki przeprowadzonych analiz dowodzą, że system subwencji rolniczych wspierających gospodarstwa ekologiczne nie umocnił ich rynkowo, czego konsekwencją jest spadek zarówno liczby gospodarstw ekologicznych, jak i powierzchni upraw. Przyczyną takiego stanu rzeczy wydaje się być również niski poziom produkcji towarowej gospodarstw ekologicznych. Należy zatem poszukiwać innych skutecznych sposobów umocnienia rynkowego gospodarstw ekologicznych. Ciekawa propozycją w tym zakresie jest inicjatywa kooperatywy Ekopole i projekt „Ekologia Plus”. Głównym celem utworzonego z czterech podmiotów gospodarczych konsorcjum jest podejmowanie działań na rzecz stworzenia korzystnych warunków do stymulowania certyfikowanej towarowej produkcji ekologicznej, czyli takiej, którą da się sprzedać po bardzo dobrych cenach. Grupa chce kompleksowo wspierać producentów rolnictwa ekologicznego, rozwijać doświadczalnictwo i badania w rolnictwie ekologicznym. Plany są bardzo ambitne i obejmują doświadczenie produkcyjne na 240 ha, które pozwoli określić, jaka jest różnica pomiędzy uprawą żyta ozimego tzw. tradycyjną metodą ekologiczną - bez jakiejkolwiek ingerencji, a uprawą ekologiczną żyta ozimego, gdzie zastosowane zostaną metody i środki dopuszczone do stosowania w tym systemie produkcji. Chodzi głównie o to, by zwiększyć efektywność tego systemu produkcji.

$\mathrm{Na}$ uwagę zasługują też konkursy cyklicznie organizowane od 10 już lat przez MRiRW i CDR. Są one prowadzone w dwóch kategoriach: „ekologia-środowisko” i „ekologiczne gospodarstwo towarowe". Celem konkursu jest zarówno popularyzacja rolnictwa ekologicznego, jak i rozpowszechnianie wiedzy z tego zakresu. $Z$ analizy informacji dostępnych na stronach internetowych poszczególnych ODR-ów i opisów laureatów w kategorii „ekologiczne gospodarstwo towarowe” wynika, że o sukcesie w tym konkursie decyduje kilka elementów. Oprócz wskaźników bezpośrednio związanych z towarowością, czyli wielkości produkcji sprzedanej jako ekologiczna, wielkości uzyskiwanych plonów i wydajności zwierząt, oceniane są również: ilość asortymentów produktów nieprzetworzonych przeznaczonych do sprzedaży, formy przygotowania produktów do sprzedaży, rozwój gospodarstwa w ostatnich 5 latach, uzyskane certyfikaty jakości produktów oraz innowacyjność, współpraca z jednostkami badawczymi, a także aktywność społeczna rolnika. Takie podejście wydaje się dość szerokie i kompleksowe, a poza tym wychodzi naprzeciw oczekiwaniom społecznym oraz skraca łańcuch dostaw. To ważne, ponieważ dla ekologicznych gospodarstw rolnych subwencje rolnicze powinny stanowić jedynie dodatkowe wsparcie finansowe i nie powinny być czynnikiem decydującym o funkcjonowaniu gospodarstwa w tym systemie produkcji.

\section{Podsumowanie}

W początkowym okresie ekologizacji polskiego rolnictwa po 2004 roku następował dynamiczny wzrost zarówno liczby, jak i powierzchni ekologicznych gospodarstw rolnych. Nie przekładało się to jednak na wielkość produkcji ekologicznej, ani rozwój lokalnego rynku żywności ekologicznej. Wydatki na żywność ekologiczną na poziomie 4 euro na 
osobę rocznie nie rokują dobrze, chociaż z danych raportu IMAS wynika, że rynek żywności ekologicznej w Polsce rozwija się bardzo dynamicznie, 10-20\% w skali roku. Spadają ceny produktów ekologicznych i wzrasta ich dostępność.

Reasumując, sukces ekologizacji polskiego rolnictwa będzie zależał przede wszystkim, od umocnienia rynkowego ekologicznych gospodarstw rolnych (wzrostu towarowości i skrócenia łańcucha dostaw żywności w rolnictwie ekologicznym) oraz budowania świadomości konsumenckiej w zakresie wyboru produktów żywnościowych (lokalnie, z produkcji ekologicznej).

\section{Literatura}

Domagalska, J., Buczkowska, M. (2015). Rolnictwo ekologiczne-szanse i perspektywy rozwoju (Organic farming - opportunities and perspectives). Problemy Higieny i Epidemiolgii, 96(2), 370-376.

Famielec, J. (2015). Ekologizacja jako paradygmat rozwoju społeczno-gospodarczego (Ecologization as paradigm of socio-economic development). W: Ekologizacja gospodarki (red. M. Kożuch) in: Ecologization of the economy). Wyd. Uniwersytet Ekonomiczny w Krakowie, 11-30.

Goraj, L. (2013). Analiza rynku sektora rolnictwa ekologicznego w Polsce (Analysis of the market of the organic farming sector in Poland). Warszawa.

Kozłowski, S. (1997). Droga do ekorozwoju (Path to eco-development). Wydawnictwo Naukowe PWN, Warszawa.

Luty, L. (2016): Rozwój rolnictwa ekologicznego na świecie (The development of organic farming in the world). Wiadomości Statystyczne, 1(656), 79-92.

Łuczka-Bakuła, W. (1994). Dylematy ekologizacji rolnictwa w Polsce (The dilemmas of polish agriculture's ecological adjustment). Ruch Prawniczy, Ekonomiczny i Socjologiczny, 56(1), 91-98.

Michnowski, L. (2014). Nauka dla życia w stanie zmian i ryzyka (Science for life in a state of change and risk). Przyszłość. Świat-Europa-Polska, 2, 140-158.

Nachtman, G. (2013). Dochodowość gospodarstw ekologicznych a wielkość użytków rolnych (Profitability of organic farmsagainst utilized agricultural area). Roczniki Ekonomii Rolnictwa i Rozwoju Obszarów Wiejskich, 100(1), 182-195.

Nowogródzka, T., Podstawka, M., Szarek, S. (2013): Towarowość a sytuacja produkcyjno-ekonomiczna gospodarstw ekologicznych w Polsce (Marketability and economic production conditions of organic farming in Poland). Wieś i Rolnictwo, 2(159), 157-168.

The World of Organic Agriculture statistic and emerging trends (2018). FIBL \& IFOAM - Organic International

Uranowska, A. (2017): Ekologiczna produkcja towarowa zbóż i roślin strączkowych (Organic commodity production of cereales and legumes), Rolnicze ABC 10(325).

Uwarunkowania ekonomiczne i społeczne rozwoju rolnictwa ekologicznego w Polsce (raport z badań) (Economic and social determinants of development of organic farming in Poland (research report)). (2017). Pobrano z: http://www.irwirpan.waw.pl/polski/Raport Uwarunkowania ekonomiczne i spoleczne rozwoju-2007.pdf.

Zawojska, A. (2011). Pogoń za rentą i lobbing we wspólnej polityce rolnej Unii Europejskiej (Rent-seeking and lobbying in the EU's common agricultural policy). Roczniki Nauk Rolniczych, Seria G, 98(3), 63-72.

Zybertowicz, A. (2010): Polityczna pogoń za rentą jako zagrożenie dla spójności społecznej i modernizacji (Część I: Perspektywa teoretyczna) (Political rent seeking as a threat to social cohesion and modernization). Nierówności Społeczne a Wzrost Gospodarczy, 16, 32-52.

Żywność ekologiczna w Polsce (Organic food in Poland) (2017): Raport IMAS. Pobrano z: http://imas.pl/wpcontent/uploads/2017/12/Zywnosc_ekologiczna_w_Polsce_2017_IMAS_International.pdf.

Do cytowania / For citation:

Brodzińska K. (2018). Ekologizacja rolnictwa w aspekcie polityki finansowego wsparcia. Problemy Rolnictwa Światowego, 18(3), 49-58; DOI: 10.22630/PRS.2018.18.3.65

Brodzińska K. (2018). The Ecologization of Agriculture in Aspect of Financial Support Policy (in Polish). Problems of World Agriculture, 18(3), 49-58; DOI: 10.22630/PRS.2018.18.3.65 